\title{
Analisis Format Ideal Transformasi Institut Menuju Universitas di PTKIN
}

\author{
AHMAD SURADI \\ Fakultas Tarbiyah dan Tadris IAIN Bengkulu \\ Jl. Raden Patah, Kelurahan, Pagar Dewa, Selebar, Kota Bengkulu, 65144 \\ e-mail: suradi@iainbengkulu.ac.id
}

\begin{abstract}
The change of IAIN to UIN is of course not just a change of status from the original institute to university, but also includes changes in the structure of the existing scientific buildings therein. Thus, the problem discussed is how the ideal format in the change of State Islamic Religious College (PTKIN). Writing this scientific paper is a type of reseach library research using a qualitative approach. PTKIN Transformation, At least there are fundamental things that require IAIN when it becomes a UIN must be done, namely: first, Eliminate or at least reduce the dichotomy of science that has been descended most of the Muslims. Second, Open access to larger inputs, and able to perform vertical mobility in the community. Third, Opens greater opportunities for Islamic education to contribute to the information society. In addition, the effort to transform IAIN into UIN should be the strong will, sincerity, and capabilities possessed by current IAIN managers and managers, as well as consideration of their ability to manage, improve and develop on an ongoing basis, both in administration and in academia.
\end{abstract}

Keywords: Transformation, Institute, Towards University

Abstrak: Perubahan IAIN menjadi UIN tentu saja bukan sekadar perubah status dari semula institut menjadi universitas, melainkan juga termasuk perubahan dalam struktur bangunan keilmuan yang ada didalamnya. Sehingga, permasalahan yang dibahas adalah bagaimana format yang ideal dalam perubahan PTKIN. Penulisan karya ilmiah ini merupakan jenis penelitian library reseach dengan menggunakan pendekatan kualitatif. Transformasi PTKIN, Setidaknya ada hal mendasar yang mengharuskan IAIN ketika telah menjadi UIN harus segera dilakukan, yakni: pertama, Menghilangkan atau paling tidak mereduksi dikotomi ilmu pengetahuan yang selama ini menghinggapi sebagian besar kaum Muslimin. Kedua, Membuka akses terhadap input yang lebih besar, serta mampu melakukan mobilitas vertikal di masyarakat. Ketiga, Membuka peluang yang lebih besar bagi pendidikan Islam untuk berkontribusi ditengah-tengah masyarakat informasi. Di samping itu, upaya mentranformasikan IAIN menjadi UIN harus adanya kemauan yang keras, kesungguhan, serta kemampuan yang dimiliki oleh para pimpinan dan pengelola IAIN saat ini, juga harus dipertimbangkan tentang kemampuan mengelola, meningkatkan dan mengembangkannya secara berkesinambungan, baik dalam administrasi maupun dalam akademiknya.

Kata Kunci: Transformasi, Institut, Menuju Universitas 


\section{PENDAHULUAN}

Jika ditinjau dari perjalanan sejarah perguruan tinggi Islam di Indonesia, maka perjalanan evolusi perkembangan ini sudah saatnya perguruan tinggi Islam itu menjadi Universitas. Mula pertama berbentuk Perguruan Tinggi Keagamaan Islam (PTKIN) ekuivalenlah sekarang dengan tingkatan sekolah tinggi, kemudian berevolusi menjadi Institut Agama Islam Negeri (IAIN) dan setelah ini telah banyak mengharapkan untuk berkembang menjadi Universitas Islam Negeri (UIN). Dalam rangka persiapan ke arah itu, beberapa IAIN telah mulai membuka beberapa fakultas dan program studi yang tidak lagi hanya tergolong kepada fakultas-fakultas keagamaan saja, misalnya IAIN Jakarta pada penerimaan mahasiswa tahun 2000/2001 telah membuka beberapa program studi di luar disiplin ilmu-ilmu agama. Misalnya, Program Studi Teknik Informatika, Program Studi Agrobisnis, Psikologi, Manajemen dan Akutansi (Kusmana dan Munadi, 2002: 28).

Beberapa tahun belakangan, di lingkungan IAIN mengemuka dengan cukup intens mengenai transformasi IAIN menjadi Universitas Islam Negeri (UIN). Perubahan ini merupakan wujud pengharapan umat Islam agar Pendidikan Tinggi Islam dikemudian hari bisa menatap masa depan dengan lebih baik. Semenjak tahun 2002 hingga saat ini tercatat setidaknya IAIN dan STAIN bertransformasi menjadi UIN berjumlah 16 Universitas bahkan untuk di pulau Sumatera sendiri telah ada 7 UIN. Sehingga ada 3 provinsi lagi di pulau Sumatera yang belum ada UINnya, yakni provinsi Bengkulu, Kepulauan Riau dan Bangka Belitung.

Tentu saja perubahan ini bukanlah sekedar perubahan status belaka, dari semula institut menjadi universitas, melainkan mengharuskan terjadinya perubahan dalam hampir seluruh aspek seperti ideologi-konseptual, sistem administrasi serta manajerial. UIN haruslah memiliki karakteristik tersendiri yang membedakannya dengan Perguruan Tinggi Umum. Bahkan juga tidak harus sama dengan Universitas Islam sejenis yang sudah lama berkembang. Dengan hadirnya UIN harus dapat memberikan banyak peran dan inovasi baru yang dapat ditawarkan. Atau dengan kata lain, kehadiran UIN harus berani tampil beda dibandingkan dengan universitas lain yang selama ini masih dalam kompetensi institusi keilmuan yang dapat dipertanggung jawabkan secara akademik dan moral. Berani tampil beda merupakan tantangan, sekaligus merupakan kesempatan mencari peluang-peluang baru sehingga peran-peran yang dimainkan akan terasa baru yang selama ini belum tergarap secara maksimal oleh perguruan Tinggi yang sudah ada.

IAIN bertransformasi menjadi UIN di era globalisasi ini, maka diharapkan dapat mencetak sarjana muslim yang memiliki dua keunggulan, yakni keunggulan di bidang sains dan teknologi sekaligus keunggulan di bidang wawasan keislaman. Misalkan di Fakultas Sains dan Teknologi mahasiswa diberikan mata kuliah Studi alQur'an, maka seharusnya materi yang diberikan tentu akan berbeda dengan materi yang diberikan pada mahasiswa Fakultas Syariah. Mata kuliah studi alQur'an bagi mahasiswa Sains dan Teknologi harus digunakan sebagai landasan/pijakan dalam rangka menggali ayat-ayat kauniyah yang tersebar di alam raya. Atau dengan kata lain materi yang diberikan kepada mahasiswa Sains dan teknologi adalah berkutat pada ayat-ayat tentang kekuasaan Tuhan, proses penciptaan manusia, kesehatan, reproduksi, lingkungan dan lainnya meskipun tidak mengesampingkan materi dasar tentang ketauhidan/keislaman.

Diakui memang, bahwa transformasi IAIN menjadi UIN bukanlah satu-satunnya solusi yang dihadapi dari berbagai problem yang dihadapi oleh PTKIN, sekedar ganti baju saja tidak cukup. Segala aspek harus diperhatikan mulai dari 
manajemen perencanaan (grand design), tenaga pengajar, fasilitas, sarana, konsep keilmuwan dan metodologi sertainput dan outpu-nya. Jangan sampai ada kesan kuliah di universitas tetapi terasa kuliah di institut.

Kegelisahan para akademisi PTKIN memang pantas terjadi, karena telah bertahun-tahun andilnya tidak terlalu berdimensi lebih besar bagi pembangunan umat dan bangsa Indonesia. Padahal peran perguruan tinggi itu dalam pendidikan sangat strategis bagi perubahan pola pikir dan tingkah laku. Salah satu hal yang dianggap memarginalkan peran IAIN adalah dikotomi keilmuan yang dianut selama ini. "Institut" telah membelenggu gerak langkah yang lebih besar dan harus diganti dengan "universitas". IAIN bercitacita untuk mengembangkan PTKIN yang dibangun atas dasar integerasi antara ilmu agama dengan ilmu umum. Namun, untuk mencapai status kelembagaan menjadi sebuah Universitas tentunya bukanlah hal yang mudah, diperlukan langkah secara konstitusional, filosofis, dan edukatif.

Pengembangan dan transformasi IAIN menjadi UIN tentu bukanlah sekadar dorongan nafsu belaka, dengan hanya menggubah struktur gedung menjadi lebih luas dan mentereng melainkan proyek tersebut merupakan proyek keilmuan dan SDM. Proyek pengembangan wawasan keilmuan dan perubahan tata pikir keilmuan yang bernafaskan keagamaan transformatif. Berangkat dari hal tersebut, penting untuk diketengahkan apa sesungguhnya urgensi yang mengharuskan perlunya perubahan IAIN menjadi UIN, Sehingga, paper ini akan berusaha mengurainya berupa format transformasi institut agama Islam menjadi Universitas Islam berkualitas menuju era globalisasi.

Berdasarkan uraian di atas, maka masalah kajian yang dibahas dalam karya ilmiah ini adalah bagaimana dasar awal dan format yang ideal dalam perubahan
Perguruan Tinggi Keagamaan Islam Negeri (PTKIN) dari IAIN ke UIN yang berkualitas dalam mengahadapi era globalisasi. Adapun tujuan kajian ini adalan untuk menganalisa dasar awal dan format yang ideal dalam perubahan Perguruan Tinggi Keagamaan Islam Negeri dari IAIN ke UIN yang berkualitas dalam mengahadapi era globalisasi.

\section{DASAR AWAL PERUBAHAN INSTITUT MENJADI UNIVERSITAS DI PTKIN}

Ide perubahan IAIN menjadi UIN sebenarnya sudah lama dirintis oleh para pendiri IAIN. Pemikiran tentang pentingnya lembaga perguruan tinggi Islam yang berbentuk Universitas di Indonesia pernah dirintis sejak zaman Mahmud Yunus. Menurutnya bahwa Universitas Islam Darul Hikmah diresmikan di Bukit Tinggi pada tahun 1957, sebelum menjadi Universitas lembaga ini bernama Perguruan Islam Tinggi Darul Hikmah yang berdiri pada tahun 1953. Ada beberapa dasar pemikiran yang menjadi landasan perubahan status dari IAIN menjadi UIN, yaitu:

1. Integrasi ilmu, menghilangkan dikotomi dualisme keilmuan.

2. Berubahnya status madrasah sebagai sekolah yang berciri khas agama Islam

3. Mobilitas dan lapangan kerja yang luas bagi lulusan PTAI (Perta, 2009).

Gagasan transformasi IAIN menjadi UIN pertama kali dikemukakan Rektor IAIN Jakarta Periode 1973-1984, Harun Nasution. Namun, gagasan itu kandas lantaran terkendala aturan dan SDM yang belum memadai. Lama tak terdengar, ide itu kembali mengemuka pada masa kepemimpinan Rektor IAIN M Quraish Shihab (1992-1998). Berbagai persiapan dilakukan, hingga ide tersebut akhirnya terealisasi pada 20 Mei 2002, periode kepemimpinan Rektor Azyumardi Azra (1998-2006). Setelah berganti nama, infrastruktur segera dibangun dan arah pengembangan diperjelas yakni menjadi universitas riset dan universitas kelas 
dunia (Daulay, 2009: 26). Disamping itu, alasan Harun Nasution ingin mengembangkan IAIN menjadi UIN dikemukakan dalam sebuah wawancara dengan Republika, pada Kamis, 28 Desember 1995. Saat itu ia sudah menjadi Direktur Program Pascasarjana. "Kita merasa yang diperlukan umat di zaman sekarang ini bukan hanya sarjana yang mengetahui ilmu agama saja, tapi juga ilmu umum. Harus diakui tidak banyak orang yang bisa menguasai keduanya secara mumpuni. Hanya orang-orang jenius saja yang bisa melakukannya," katanya (Republika, 2004).

Berangkat dari kebutuhan itu, Harun berpendapat, IAIN perlu ditransformasikan menjadi universitas, sehingga dapat membuka jurusan-jurusan umum. Harapannya tentu saja mampu mencetak sarjana yang memiliki kompetensi agama namun tidak asing dengan pengetahuan umum. Hal itu bagi Harun bukan mustahi. Sejarah mencatat seorang Ibnu Rusyd dan Ibnu Sina yang selain ahli filsafat, syariah, juga seorang dokter yang masyhur. "Kalau pada masa lampau mereka bisa menghasilkan tokoh seperti itu, kenapa kita tidak mampu menghasilkannya. Inilah dasar pendirian kita sehingga ada keinginan untuk mengubah IAIN menjadi UIN," tegas Harun (Republika, 2004).

Akhirnya, kepastian pendirian UIN itu kian jelas setelah diadakan Sarasehan UIN di IAIN Jakarta pada 22 Oktober 1994. Sarasehan itu sendiri menghadirkan sejumlah narasumber. Dari kalangan internal IAIN Jakarta seperti Quraish Shihab, Harun Nasution, dan Zakiah Daradjat. Dari Departemen Agama seperti Atho Mudzhar, dari perguruan tinggi umum seperti Asri Rasyad dari YARSI, Hanna Djumhana Bustaman dan Laode M Kamaluddin dari UI, dan Ahmad Baiquni dari BPPT. Usai sarasehan, Departemen Agama menetapkan IAIN Jakarta menjadi pilot project dan mengharapkan agar upaya pengembangan IAIN menjadi UIN ini didahului dengan studi kelayakan yang meliputi pengembangan kelembagaan, pengembangan pengembangan pengembangan ketenagaan, kurikulum, pengembangan sarana dan prasarana, dan penyusunan RIP UIN.

Namun pada kenyataannya, yang terjadi hinggi detik ini yang kemudian menjadi sebentuk kegelisahan yang menghantui PTKIN adalah menyangkut cara pandang tentang agama dan ilmu yang bersifat dikotomik, yakni menempatkan masing-masing agama dan ilmu secara terpisah. Hal ini terjadi karena ajaran Islam yang diyakini bersifat universal, ternyata pada wilayah implementasi justru diposisikan secara marginal dan dipandang kurang memberikan kontribusi yang signifikan kepada pengembangan peradaban umat manusia. Kemajuan ilmu pengetahuan dan teknologi yang sedemikian cepatnya, seperti yang dapat kita saksikan saat ini, dipandang bukan merupakan sumbangan perguruan tinggi Islam, melainkan hasil jerih payah perguruan tinggi yang tidak membawa-bawa label Islam.

Menurut pandangan Abdullah, setidaknya ada dua faktor yang mendukung cita-cita intergarasi dua arus epistemologi tersebut; pertama, tinjauan historis. Dalam perspektif historis, dalam peradaban pra-modern seperti Yunani, Cina, India dan peradaban Islam Klasik, paradigma ilmu pengetahuan (yang lebih dikenal dengan paradigma ilmu pengetahuan tradisional) adalah bersifat intergratif. Paradigma integratif (memadukan dimensi empirik dan spiritual serta memandangnya sebagai satu kesatuan) seperti inilah yang diadopsi oleh peradaban Islam ketika bersentuhan dengan peradaban Yunani yang selanjutnya 'dicerna' secara assimilatif dengan kekuatan pandangan Islam menjadi paradigma filsafat dan ilmu pengetahuan Islam (Abdullah, 2007: 182). Kedua, faktor eksternal. Maksudnya adalah adanya kritik terhadap klaim 
superioritas ilmiah sains Barat modern itu sendiri. Secara gamblang, Osman Bakar seperti yang disitir oleh Abdullah mengemukakan bahwa gagasan hanya satu metodologi saja yang bertanggung jawab atas terciptanya sains itu telah tersingkirkan oleh sejumlah besar karya tentang metodologi sains, yang banyak diterbitkan selama ini. Kritik ini mencakup tiga hal, yaitu :

1. Pada dimensi aksiologis, bahwa filsafat sains Barat bersifat utilitarian.

2. Secara radikal dilakukan klaim objektivitas dan netralitas sains.

3. Terhadap teori ilmu yang objektif yang dikembangkan oleh tokoh-tokoh seperti Descartes dan Popper (Ali, 2007: 371).

Jika diruntut, akan banyak sekali side-effect dari disintegrasi ilmu agama dan ilmu sekular. Misalnya timbulnya ambivalensi oreantasi pendidikan tinggi Islam, dari sini akan menimbulkan efek turunan berupa diskoneksi antara porsi materi pendidikan Islam dan materi pendidikan sekuler dalam prosentasi tertentu. Pada giliran selanjutnya pendidikan tinggi Islam tidak lagi sepenuhnya bermuara kepada pencapaian tujuan Pendidikan tinggi Islam itu sendiri, ironisnya, juga tidak mampu mencapai tujuan pendidikan Barat. Kemudian disintegrasi tersebut juga akan memicu kesenjangan antara sistem yang dikembangkan pendidikan tinggi Islam dengan ajaran Islam, sebab sistem pendidikan yang bersifat ambivalen mencerminkan padangan dikotomis yang memisahkan ilmu agama dan ilmu sekuler, yang sejatinya menurut pandangan Islam keduanya tidak terpisah, karena Islam memiliki epistemologi yang bersifat integralistik. Pada wilayah teknis, pola pendidikan tinggi seperti ini akan melahirkan output berupa individu yang mudah terjebak pada psuedoscience (sains palsu) serta tidak cukup terampil dalam mengeksplor ajaran agamanya.
Asumsi yang dibangun adalah IAIN yang hanya dapat menyelenggarakan program studi keagamaan saja dinilai akan melestarikan dikotomi tersebut. Dari itu, persoalan dikotomi perlahan akan dapat direduksi untuk kemudian secara perlahan dapat dihapuskan secara total dengan diusahakannya pengintegrasian antara ilmu agama dengan ilmu sekular dalam satu lembaga pendidikan seperti UIN. Selain itu, universalitas ajaran Islam juga memberikan inspirasi yang sangat kuat dalam mengembangkan PTKIN secara lebih intensif. Sebab itu, transformasi institut menjadi universitas dinilai sangat relevan, karena mampu menjadi rumah bagi berbagai macam rumpun ilmu pengetahuan umum dengan menjadikan Islam sebagai struktur penyangganya.

1. Tujuan institusional IAIN

Tujuan institusional IAIN dinilai tidak lagi relevan untuk terus dipertahankan di era informasi seperti sekarang ini. Pendirian IAIN bertujuan untuk memberi pengajaran tinggi dan menjadi pusat untuk mengembangkan dan memperdalam ilmu pengetahuan tentang Agama Islam. Dengan kata lain, IAIN bertujuan untuk memperbaiki dan memajukan pendidikan tenaga ahli agama Islam guna keperluan pemerintah dan masyarakat. Dari sini jelas bahwa pada dasarnya IAIN beroreantasi untuk mencetak pegawai negeri (white collar job), lebih tegasnya untuk bekerja di lingkungan Depertemen Agama. Dalam perkembangan selanjutnya, hal ini dirasakan semakin tidak memadai, karena lapangan kerja dilingkungan Departemen Agama itu sendiri juga sangat sedikit dan terbatas. Padahal IAIN setiap tahunnya melepaskan wisudawan sebanyak dua kali dengan jumlah keseluruhan mencapai puluhan ribu (Fadjar, 2006: 37).

Tentu saja hal tersebut merupakan ironi serta pemandangan yang tidak seharusnya. Barangkali berangkat dari sinilah, akhirnya sering mengemuka stigma mengenasi isu bahwa PTKIN 
kurang diminati oleh masyarakat, bahkan dari kalangan masyarakat yang notabene adalah lumbung sumberdaya bagi PTKIN sendiri seperti kalangan santri. Kurang tertariknya masyarakat untuk menjadikan PTKIN seperti IAIN sebagai pilihan menurut pandangan Malik Fadjar sebagaimana dikutip Suwito dan Suprapto (2004: 160-161), terjadi bukanlah karena adanya pergeseran nilai atau ikatan keagamaan yang memudar, melainkan karena sebagian besar kurang menjanjikan masa depan dan kurang responsif terhadap tuntutan dan permintaan saat ini maupun mendatang. Padahal paling tidak ada tiga hal yang menjadi pertimbangan masyarakat dalam memilih lembaga pendidikan, yaitu nilai (agama), status sosial dan cita-cita. Masyarakat yang terpelajar akan semakin beragam pertimbangannya dalam memilih pendidikan bagi anak-anaknya. Hal ini sama sekali berbeda dengan kondisi tempo dulu yang masih serba terbatas dan terbelakang.

Implikasi dari pandangan tersebut terhadap IAIN adalah bahwa IAIN sebagai lembaga pendidikan tinggi Islam yang masih berorentasi pada fokus kajian keislaman dianggap belum bisa menjanjikan karena belum mampu menyiapkan lulusan untuk berkompetisi di tengah-tengah arus globalisasi, yang identik dengan kemajuan sains dan teknologi. Atas dasar itu cukup relevan jika kemudian IAIN ditransformasi menjadi UIN. Selain untuk meningkatkan daya serap input yang lebih luas, transformasi menjadi UIN juga akan lebih memberi harapan dan peluang kepada para lulusannya untuk dapat melakukan mobilisasi yang lebih intens ditengahtengah masyarakat, yang sama sekali berbeda dengan lulusan IAIN yang hanya mampu menaungi "pekarangan" Kementerian Agama.

2. Agar pendidikan tinggi Islam mampu menginstal produk pemikiran ditengah-tengah masyarakt informasi.
Dalam hal ini perkembangan yang saat ini dapat kita saksikan dengan begitu menyeruaknya berbagai nilai-nilai dan pemikiran yang beragam, bisa jadi menuju ke arah yang positif dan bisa pula ke arah yang negatif, tergantung siapa yang paling banyak menginstal konsep-konsep, produk pemikiran, budaya dan nilai kedalamnya (Idris, 2008: 192). Banyaknya menginstal produk pemikiran bangsa Barat, sesungguhnya banyak kritik yang dilakukan oleh masyarakat ilmiah outsider, berupa kritik eksternal, seperti Roszak, Nasr dan Illich serta juga kalangan insider seperti Whitehead, Thomas Kuhn, Mitrof, Rovetz dan lain-lain yang menghendaki adanya epistemologi alternatif selain epistemologi yang dikembangkan di Barat (Fadjar, 2006: 42). Dalam kondisi yang demikianlah hendaknya perguruan tinggi Islam di Indonesia menunjukkan kiprahnya sebagai kontributor produk pemikiran.

Dalam hal ini, IAIN agaknya masih kerepotan dalam menanggapi era informasi dikarenakan secara internal fondasi epistemologi dalam membangun produk pemikiran Islam yang berkembang di IAIN masih terdisintegrasi. Fenomena ini kemudian menyebabkan terjadinya kesenjangan tata berpikir antar lembaga-lembaga keagamaan dan IAIN dengan tuntutan masyarakat kontemporer. Orientasi tata pikir lama atau pemikiran tradisional sangat kuat dan menggejala di dalam tubuh IAIN. Sementara IAIN telah berada ditengahtengah masyarakat informasi global yang penuh dinamika, pluralistik dan perubahan-perubahan yang terus berjalan tanpa bisa diprediksi (unpredictable) dan dicegah.

Sebab itu, tidak banyak yang bisa diharapkan dari kalangan IAIN untuk memberikan sumbangsih kepada masyarakat dalam menyongsong dan menjalani era informasi. Para alumni IAIN masih berada pada fase melek agama, semetara ekspektasi masyarakat saat ini sangat beragam sehingga tidaklah cukup 
dengan hanya menguasai ilmu agama sementara sama sekali buta terhadap ilmu-ilmu lainnya, dan ini sesungguhnya adalah problem turunan dari adanya dikotomi ilmu yang merambah umat Islam. Akibat dari itu semua adalah ruang gerak dan partisipasi intelektual IAIN masih terbatas dan bahkan cenderung terpinggirkan, apalagi jika jika dibandingkan dengan peranan dan pengaruh kalangan terpelajar dari berbagai perguruan tinggi negeri lainnya.

\section{PENTINGNYA TRANSFORMASI PARADIGMA IAIN MENJADI UIN DI ERA GLOBALISASI}

Orientasi pendidikan tinggi Islam di Indonesia, sebagai subsistem pendidikan tinggi nasional, ikut terpengaruh pada transfer of knowledge sebatas yang terkait erat dengan masalah kerja dan perolehan gelar akademik; bukan untuk mengembangkan kemampuan manusia secara kaffah. Pendidikan tinggi Islam seharusnya mengembangkan tiga perangkat manusia, yang berupa akal, hati, dan fisik (terutama pancaindra) secara maksimal. Kritik Djohar terhadap pendidikan Islam bahwa pendidikan tinggi di Indonesia salah dalam hal (1) kurang memberi kondisi bagi tumbuh kembangnya akal, (2) kurang menumbuhkembangkan hati, dan (3) kurang menumbuhkembangkan fisik manusia, terutama pancaindra (Djohar, 2007).

Menurut Zamroni (2005: 61), secara paradigmatis pekerjaan profesional dapat dikelompokkan ke dalam dua kategori, yaitu hard profession dan soft profession. Suatu pekerjaan dikatakan hard profession apabila pekerjaan tersebut diwujudkan dalam perilaku dan langkahlangkah yang jelas dan relatif pasti. Pendidikan yang diperlukan bagi profesi ini yaitu mengahsilkan output pendidikan yang dapat distandarisasikan. Artinya, kualifikasi lulusan jelas dan seragam di manapun pendidikan tersebut diberlangsung. Sebaliknya, soft- profession adalah diperlukan kadar seni dalam melaksanakan pekerjaan tersebut.Ciri pekerjaan tersebut tidak dapat dijabarkan secara detail dan pasti. Sebab, langkah-langkah yang diambil dalam pekerjaan ini sangat ditentukan oleh situasi dan kondisi tertentu. Implikasi kategori ini tidak menuntut pendidikan yang dapat menghasilkan lulusan yang dibekali dengan kemampuan minimal.

Perguruan Tinggi Keagamaan Islam, sekarang dihadapkan pada persoalanpersoalan yang menuntut perhatian segera ditangani. Persoalan-persoalan itu antara lain: (1) citra umat Islam sangat buruk di mata Internasional, (2) peradaban umat Islam terbelakang dibandingkan Barat, (3) umat Islam terdera oleh berbagai krisis, (4) dihadapkan pada problem dikotomi keilmuan yang sangat akut (ilmu tradisional dengan ilmu sekuler modern), (5) Perguruan Tinggi Kegamaan Islam dituntut dapat menghahsilkan alumni bertakwa yang memiliki tiga kemampuan, yaitu kemampuan untuk menganalisis, kemampuan untuk berinovasi dan kemampuan untuk memimpin.

Disadari atau tidak, peradaban umat Islam pernah mengalami pasang surut, naik turun dan bergelombang. Realitas menunjukkan bahwa peradaban umat Islam sekarang sedang terbelakang atau terpuruk. Menurut Ismail Raji al-Faruqi (2009: 1), umat Islam sekarang benarbenar terpuruk dan terhina baik secara fisik maupun mental. Citra umat Islam dicirikan dengan agresif, destruktif, ekstremis, mengingkari hukum, fanatik, fundamentalis, teroris, dan seterusnya. Disamping itu, salah satu indikasi kemunduran peradaban umat Islam, menurut Fazlur Rahman (1994: 175), adalah ketidakmampuan mereka memberikan solusi atas berbagai problem yang dihadapinya. Padahal kehidupan mereka selanjutnya akan ditentukan oleh sejauh mana mereka sanggup menghadapi 
tantangan-tantangan yang mereka hadapi secara kritis dan kreatif.

Dinamika peradaban umat manusia terus berjalan hingga sekarang dalam menghadapi abad 21, suatu abad yang ditandai oleh globalisasi. Salah satu ciri pokok masyarakat abad ini adalah lahirnya suatu masyarakat megakompetisi, yaitu suatu masyarakat yang segala sesuatunya berjalan melalui kompetisi. Kompetisi menghendaki segala sesuatunya serba terbaik. Dalam kaitannya dengan IAIN adalah lembaga tersebut dituntut dapat menghasilkan alumni yang dapat berkompetisi dalam era global ini.

Abdul Munir Mulkan (2001: 7) melihat ada dua permasalahan yang perlu dijernihkan dalam pendidikan Islam, yaitu masalah yang berkaitan dengan konsep ilmu dan masalah ontologi. Menurut Fazlur Rahman (1994: 180), problem pendidikan Islam yang paling mendasar dewasa ini adalah problem ideologi. Umat Islam tidak dapat mengaitkan secara efektif pentingnya pengetahuan dengan orientasi ideologinya. Akibatnya mereka tidak terdorong untuk belajar. Bahkan, mereka tidak sadar kalau berada di bawah perintah moral kewajiban Islam untuk menuntut ilmu pengetahuan.

Dengan hal tersebut, problem berikutnya adalah adanya dualism sistem pendidikan umat Islam sebagai akibat dari adanya dikotomi ilmu dalam Islam. Pada satu sisi, disebut sistem pendidikan Islam, mulai dari madrasah Ibtidaiyah (MI) sampai kepada Perguruan Tinggi Keagamaan Islam, yang begitu tertinggal sehingga hasilnya dapat mengecewakan. Kebanyakan produk dari sistem ini tidak dapat hidup di dunia modern dan tidak bisa mengikuti perkembangan zaman. Pada sisi lain, ada sistem pendidikan modern (umum) yang dilaksanakan mulai dari Sekolah Dasar (SD) sampai Perguruan Tinggi Umum (PTU), di mana sistem ini telah berkembang tanpa menyentuh sama sekali ideologi dan nilai-nilai Islam. Hasilnya sangat strategis, dasar minimal dari rasa jujur dan tanggung jawab pun tidak muncul. Maka kedua sistem pendidikan ini sama-sama tidak beresnya.

Dalam pandangan Azyumardi Azra yang dikutip Nata (2005: 23), juga dikatakan (salah satu arsitek penting dalam proyek perubahan IAIN ke UIN) bahwa gagasan dan konsep dasar pengembangan IAIN menuju UIN tak lepas dari beberapa masalah yang dihadapi IAIN dalam perkembangannya selama ini. Pertama, IAIN belum berperan secara optimal dalam dunia akademik, birokrasi dan masyarakat Indonesia secara keseluruhan. IAIN lebih banyak berperan di masyarakat karena dalam konteks dakwah. Kedua, kurikulum IAIN belum mampu merespon perkembangan IPTEK dan perubahan masyarakat yang semakin kompleks.

Ada empat hal prinsip yang harus dicermati menangani dunia pendidikan tinggi Islam dengan mengambil UIN sebagai pola, yaitu: Pertama. Proses pertumbuhan (growth) baik dari aspek institusional, konseptual, maupun prosesnya.Kedua. Perubahan (change), UI $\mathrm{N}$ adalah sebuah perubahan institusi pendidikan dari institut atau sekolah tinggi ke universitas. Perubahan ini harus disikapi dan diapresiasi secara profesional bagaimana "mengubah" struktur akademik, manajemen, dan macammacamnya yang lain. Ketiga, Pembaruan (reform), UIN bukan sekadar perubahan status tetapi bagaimana mengembangkan pembaruan baik ke dalam maupun ke luar. Keempat, Kesinambungan (continuity). Mengelola pendidikan adalah mengelola masa depan. Masa depan adalah abad IT (Ilmu dan Teknologi). Untuk itu, maka mengelola kurikulum pendidikan harus mampu menangkap, mengolah, dan mengelola informasi untuk memasuki dunia masa depan itu (Fadjar, 2005: 40-41).

Apa yang dikemukakan Fadjar tersebut di atas, mengenai pengembangan perguruan tinggi keagamaan Islam (UIN) ini, adalah karena 
pendidikan bukan sekadar "perkumpulan kemasyarakatan" (community), melainkan sebuah investasi manusia/kemanusiaan (human invesment) dalam rangka membangun peradaban. Peradaban Islam harus dibangun melalui UIN. UIN sekurang-kurangnya, adalah usaha memainkan peran umat Islam ke dalam persaingan dan pergaulan global (the global game) yang semakin meningkat. "Umat Islam harus mengambil peran dalam percaturan dunia global. Bukan sekadar penonton, pengadopsi, dan pengkonsumsi produk-produk global, tapi bagaimana menjadi penggagas utama perubahan dan pembaruan global itu.

\section{FORMAT PERUBAHAN IAIN MENJADI UIN YANG BERKUALITAS DI ERA GLOBALISASI}

Merupakan sebuah keniscayaan bahwa kehadiran lembaga pendidikan Islam yang berkualitas dalam berbagai jenis dan jenjang pendidikan sesungguhnya sangat diharapkan oleh kaum Muslimin. Bahkan kini mulai terasa sebagai sebuah kebutuhan yang mendesak bagi kalangan Muslim kelas menengah keatas yang secara kuantitatif terus meningkat belakangan ini. Fenomena sosial seperti ini kemudian menjadi tema sentral dan momen untuk "berkaca diri" bagi pengelola lembaga pendidikan Islam dalam melakukan pembaharuan dan pengembangan. Namun perlu disadari sedari awal bahwa pengembangan pendidikan Islam bukanlah perkara yang enteng dan mudah, sebab memerlukan adanya perencanaan yang ekstra matang, utuh, terpadau dan menyeluruh. Sebagaimana dijelaskan oleh mantan Menteri Pendidikan Malik Fadjar yang dkutip Idris (2008), bahwa semuanya itu memerlukan adanya kejelasan terhadap masa depan yang akan dicapai dan dijanjikan.

Oleh karena itu, sudah semestinya PTKIN memiliki pilihan yang kritis untuk mengembangkan citra dirinya dengan menekankan pada aspek kualitas di atas kuantitas. Sehingga mampu berbicara banyak dalam pergulatan sistem pendidikan tinggi di Indonesia. Untuk itu, beberapa orientasi yang patut dijadikan pijakan dan sekaligus ditumbuhkembangkan IAIN dalam mempersiapkan diri untuk mentransformasi menjadi UIN, guna menjadi perguruan tinggi yang berkualitas, antara lain:

\section{Intellectual Oriented}

Pendidikan hendaknya diorientasikan kepada upaya peningkatan kecerdasan peserta didik atau mahasiswa, yang sangat sesuai dan berorientasi terhadap tujuan perguruan tinggi itu sendiri. Orientasi ini mengarahkan PTKIN untuk menjadi pusat lembaga pengembangan ilmu pengetahuan agama, bukan pusat doktrin Islam. Dengan perkataan lain, pola dogmatis cenderung membawa mahasiswa bersifat pasif dan rendah stimulan daya nalar serta kreatifitasnya. Sudah seharusnya membentuk mahasiswa yang berkualitas dan berwawasan luas, sehingga tidak terkesan hanya mencari gelar dan ijazah saja. Output PTKIN tidak menjadi alumni yang serba tanggung, tidak mengusai dan memiliki pengetahuan yang mumpuni baik dari segi pengetahuan agama ataupun pengetahuan umum, misalnya kurangnya penguasaan ilmu keagamaan, penguasaan bahasa Asing (Arab dan Inggris), kurang menguasai IT dan lain sebagainya.

\section{Professional Oriented}

Perguruan tinggi Islam harus berorientasi kepada upaya peningkatan kemampuan profesional atau ketrampilan praktis (PP No. 60 Tahun 1999 tentang Penyelenggaraan Perguruan Tinggi). Ini dimaksudkan agar peserta didik memiliki kemampuan dalam memberikan jawaban terhadap persoalan-persoalan aktual dan tuntutan zaman. Hal ini perguruan tinggi keagamaan Islam mesti dipenuhinya tenaga pengajar/dosen yang profesional 
sesuai dengan kompetensinya. Dalam arti, tidak asal meletakkan dosen pengampu yang dianggap serba bisa, mampu mengajar segala mata kuliah, akan tetapi memenuhi tenaga pengajar sesuai dengan kebutuhan mata kuliah dan program studi. Jangan sampai terjadi merekrut tenaga pengajar karena faktor kedekatan, kekeluargaan, bukan karena profesional dan bahkan tenaga administrasipun menjadi tenaga pengajar. Karena hal ini akan menghilangkan proses transfer of knowledge and skill yang maksimal dalam kegiatan belajar mengajar.

Selain itu, terkait erat dengan lapangan pekerjaan, maka yang perlu diperhatikan juga adalah tidak saja melahirkan out-put yang profesional di bidangnya, dengan memenuhi tenaga pengajar yang profesioanal, akan tetapi juga selayaknya di-manage secara profesional pula oleh para pengelolanya. Dengan demikian, posisi-posisi kunci dalam perguruan tinggi Islam, seharusnya dijabat oleh mereka yang terbukti berprestasi akademik, bukan oleh orang yang memiliki masa kerja lama dan faktor kedekatan emosional "koncoisme" tanpa prestasi akademik.

\section{Moral Oriented}

Sekalipun prinsip ini meduduki urutan terakhir, tetapi tidak berarti keberadaannya kurang signifikan. Justru dalam bingkai citra diri PTKIN, orientasi yang disebut terakhir ini harus dikedepankan di atas segala-galanya. Ia mesti dijadikan parameter pertama dan utama bagi jati diri PTKIN. Lebih-lebih pada saat bangsa kita sedang dilanda dekadensi moral, baik berupa penyalahgunaan kekuasaan, maupun praktek penyalahgunaan obat-obat terlarang. Dengan bercermin pada berbagai kasus di atas, maka sudah seharusnya PTKIN menjadi proyek percontohan (pilot project) bagi satusatunya lembaga yang tidak tersentuh oleh praktek penyalahgunaan apapun juga, dengan menjunjung tinggi moral dan akhlak di kalangan segenab civitas akademikanya. Sebab, jika moralpun tidak mampu kita tegakkan, lalu apa bedanya PTKIN dengan lembaga-lembaga lain, tragisnya apa lagi yang dapat kita banggakan di tengah-tegah masyarakat.

Di samping itu, agar transformasi IAIN ke UIN tidak hanya sebagai perubahan status belaka, tetapi dapat membentuk lembaga pendidikan tinggi Islam yang berkualitas yang outputnya dapat berdaya saing di era globalisasi ini. Maka perlu memperhatikan dan mesti diupayakan komponen-komponen ini, yaitu:

1. Tenaga pengajar/dosen, yakni dosen yang mumpuni, baik dari sisi akhlak, spiritual, latar belakang pendidikan, jabatan akademik, dan kualitas serta kuantitas produktivitasnya.

2. Sarana dan prasarana yang memadai sebagai fasilitas proses pembelajaran dan kegiatan akademik. Karena hal ini merupakan sangat mendukung dalam peningkatan kualitas suatu perguruan tinggi, misalnya ruang belajar, ruang dosen, tempat diskusi-diskusi dosen, media cetak untuk karya-karya dosen, IT, fasilitas kegiatan keagamaan, kesenian, olahraga dsb. Tanpa terpenuhinya fasilitas ini, akan sulit mewujudkan kualitas output yang berdaya saing,

3. Perpustakaan yang memiliki koleksi maupun pelayanan yang baik.

4. Tempat pelayanan administrasi kampus harus mampu memberikan pelayanan yang cepat, tepat, dan santun. Dalam melayani siapa saja, entah dosen, karyawan ataupun mahasiswa harus didasarkan pada prinsip-prinsip bangunan akhlakul karimah.

5. Sumber pendanaan yang luas dan kuat. Kelemahan sebagian besar perguruan tinggi Islam adalah dalam hal pengembangan pendanaan. Akibatnya, mereka tidak mampu membangun performance kampus yang gagah dan bersih, memberikan imbalan tenaga pengajar yang cukup, merumuskan 
program peningkatan kualitas serta inovasi sesuai dengan tuntutan masyarakat.

Atas dasar itulah, menurut penulis, kampus tersebut menjadi produktif, berkualitas dan berwibawa di tengahtengah masyarakat perguruan tinggi pada umunya. Namun hal yang lain perlu diperhatikan dan dipersiapkan guna menformat IAIN menuju UIN agar tidak terjebak dengan permasalahanpermasalahan dalam peran strategisnya sebagai ujung tombak pembangunan, yaitu:

1. Perencanaan dan Pelaksanaan Pendidikan

Dari segi perencanaan dan pelaksanaan pendidikan ini dapat dikembangkan pemikiran sebagai berikut:

a. Upaya peningkatan kreativitas dan kesadaran waktu lebih mendapat perhatian yang lebih besar, dalam rangka pendidikan berpikir (how to think) sedini mungkin.

b. Membekali mahasiswa dengan kesadaran informasi. Sebab orang yang mempunyai kesadaran informasi yang tinggi adalah orang yang mampu menerima dan mengelola informasi menjadi modal kehidupan.

c. Perlu dikembangkan kegiatan kokurikuler yang bertujuan untuk merangsang perilaku yang berorientasi pada prestasi dan kecepatan (speed) (Djumransyah, 2006: 12).

2. Kesenjangan antara sistem pendidikan Islam dan ajaran Islam

Pada realitasnya, sistem pendidikan di IAIN masih bersifat ambivalen mencerminkan pandangan yang dikotomis, secara teoritis ingin mengintegrasikan antara ilmu dan agama, tetapi dalam tataran realitas masih terjadi dualisme. Hal ini jelas sangat bertentangan dengan konsep Islam yang mengajarkan kesatuan dan integritas antara keduanya. Ketika kelak bertransformasi menjadi UIN, sistem semacam ini jangan sampai tetap berjalan. Karena diakui atau tidak, sebagaimana diungkapkan oleh Candra Dewi (2004: 21), bahwa akan semakin menjauhkan diri dari cita-cita ideal pendidikan Islam dan begitu sebaliknya ilmu pengetahuan dan teknologi akan menjadi bebas nilai (valuefree). Mestinya dikembangkan beramal ilmiah, berilmu amaliah yang dipandu oleh syari'ah, yang akhirnya membentuk cerdas secara vertikan dan pintar secara horizontal.

\section{Metodologi dan Teknologi}

Di lingkungan IAIN seringkali terjebak dengan pola pengajaran dengan metodologi yang statis. Tidak banyak melakukan pembenahan atau inovasi apalagi reformasi yang strategis dan adaptif. Dengan kenyataan ini seringkali kita mendengar sinyalemen bahwa lembaga pendidikan Islam kaya materi keagamaan namun kering metodologi. Ketiga nantinya menjadi UIN, jangan sampai hal ini dilestarikan, tetapi justru harus diinovasi sistem pendidikannya. Adanya orientasi yang seimbang antara materi keagamaan, metodologi dan penguasaan teknologi.

4. Dunia Pendidikan dan Dunia Kerja

Saat ini masih banyak lulusan IAIN yang tidak mendapat pekerjaan di sektor formal, penyelenggaraan pendidikan seperti UIN harus mampu menyalurkan para alumninya ke dunia kerja. Paling tidak, menurut Siti Musdah Mulia (2004: 6), "Harus ada pembelaan terhadap masyarakat untuk mengehentikan malpraktik di perguruan tinggi Islam". Misalnya sinergi antara UIN dengan lembaga-lembaga usaha, baik pemerintah maupun swasta. Tentunya juga UIN mencetak lulusan yang berkualitas, trampil dan handal.

Sebagaimana konsep Abuddin Nata (2010: 83), bahwa pendidikan tinggi Islam harus mampu menyiapkan sumber daya manusia yang tidak sekedar penerima arus informasi global, tetapi harus memberikan bekal kepada mereka agar dapat mengolah, menyesuaikan, dan mengembangkan apa yang diterima melalui arus informasi itu, yaitu manusia 
yang kreatif dan produktif, sehingga pendidikan tinggi Islam dalam hal ini harus ditempatkan pada visi sebagai agen pembangunan dan dan perkembangan yang tidak ketinggalan zaman. Manusia yang kreatif dan produktif ini yang harus dijadikan visi pendidikan termasuk pendidikan tinggi Islam, karena manusia yang demikianlah yang didambakan kehadirannya, baik secara individual, sosial, maupun nasional. Masyarakat akan sangat kecewa manakala dunia pendidikan justru menghasilkan manusia yang malas, tradisional, kurang peka dan konsumtif.

Dengan demikaian, menurut penulis, ketika IAIN menjadi UIN harus memperioritaskan kecerdasan intelektual, keterampilan, dan menumbuhkan kecerdasan emosional. Sehingga, UIN sudah berubah; pertama, ke orientasi nilai dan idealisme yang berjangka panjang dari yang bersifat materialisme, individualisme, dan mementingkan tujuan jangka pendek. Kedua, metode yang diterapkan tidak bertolak dari pandangan yang melihat manusia yang bukan hanya potensi intelektual, tetapi juga potensi emosional. Ketiga, menjadi pendidikan tinggi Islam yang mengarahkan mahasiswanya untuk mampu merespon berbagai masalah aktual yang muncul di masyarakat, sehingga terjadi kesenjangan antara dunia pendidikan tinggi Islam dengan dunia kehidupan di masyarakat.

5. Ruang dan Waktu Perkuliahan

IAIN yang dari pola kampus terpadu, susunan fakultas, ruang belajar/kuliah dan jadwal perkuliahan serta ketentuan waktu ujian, semua masih terjebak dalam kendala ruang dan waktu yang berlaku bagi IAIN. Semua teknologi informasi dan komunikasi kini telah tersedia, berkembang pesat dan sudah banyak digunakan, akan tetapi masih belum banyak yang merintis menggunakannya secara terpadu untuk benar-benar lepas dari kendala ruang dan waktu yang telah menjebak selama ini. Semua sarana tersebut UIN memungkinkan dapat alih informasi dan ilmu tidak lagi tergantung pada pertemuan tatap muka berkala antara masing-masing pengajar dan mahasiswanya pada waktu dan tempat tertentu.

6. Metodologi Pembelajaran

Dalam hal ini perlu memformulasikan metodologi yang menjanjikan; antara lain:

a. Metode diakronis, yaitu memberikan kemungkinan kepada mahasiswa untuk mengadakan studi komparasi dengan berbagai hasil penemuan dan pengembangan suatu cabang ilmu pengetahuan.

b. Metode pemecahan masalah (problem solving), yakni melatih mahasiswa berhadapan dengan berbagai masalah dan alternatif pemecahannya.

c. Metode emperis, yaitu membawa mahasiswa untuk mempelajari ilmu pengetahuan melalui proses realisasi dan aktualisasi tentang norma-norma dan kaidah-kaidah ilmu pengetahuan tertentu melalui suatu proses aplikasi yang menumbuhkan suatu interaksi sosial yang kemudian secara deskriptif dapat merumuskan suatu sistem norma yang baru.

7. Bidang Ilmu yang Dikembangkan

Menurut Amin Abdullah (2004: 26), konten "Jaring Laba-laba" keilmuan terdiri 4 lapis. Lingkar lapis pertama (paling dalam) adalah Al-Qur'an dan As-Sunnah, lapis kedua memuat 8 ilmu keislaman yang berkembang dan terus dipertahankan, yaitu: Kalam, Falsafah, Tasawuf, Hadits, Tarikh, Fiqih, Tafsir, dan Lughah. Sedangkan yang harus dikembangkan UIN selanjutnya adalah: sosiologi, hermenitik, filologi, semiotik, fenomenologi, psikologi, filosofia, sejarah, antropologi, dan arkeologi. Sedangkan menurut Imam Suprayogo (2004: 32) mengusulkan sebagaimana yang dikembangkan di UIN yang disebut sebagai ilmu modern dengan "Pohon Ilmu" nya yaitu: ilmu kedokteran, filsafat, psikologi, ekonomi, sosiologi, teknik, dan lain-lain. 
Dengan beberapa uraian di atas, perguruan tinggi Islam mampu menyiapkan sumber daya manusia yang tidak sekedar penerima arus informasi global, tetapi memberikan bekal kepada para mahasiswanya agar dapat mengolah, menyesuaikan, dan mengembangkan apa yang diterima melalui arus informasi itu, yaitu manusia yang kreatif dan produktif, sehingga pendidikan dalam hal ini harus ditempatkan pada visi sebagai agen pembangunan dan dan perkembangan yang tidak ketinggalan zaman. Alumni yang kreatif dan produktif ini yang harus dijadikan visi perguruan tinggi Islam, karena alumni yang demikianlah yang didambakan kehadirannya, baik secara individual, sosial, maupun nasional. Masyarakat akan sangat kecewa manakala dunia perguruan tinggi Islam justru menghasilkan manusia yang malas, tradisional, kurang peka dan konsumtif.

Dengan demikian, upaya mentranformasikan IAIN menjadi UIN harus adanya kemauan yang keras, kesungguhan, serta kemampuan yang dimiliki oleh para pimpinan dan pengelola IAIN saat ini, juga harus dipertimbangkan tentang kemampuan mengelola, meningkatkan dan mengembangkannya secara berkesinambungan, baik dalam administrasi maupun dalam akademiknya. Hal ini perlu ditegaskan karena beban yang harus dipikul dan permasalahan yang harus diatasi juga akan semakin berat, besar dan kompleks.

\section{PENUTUP}

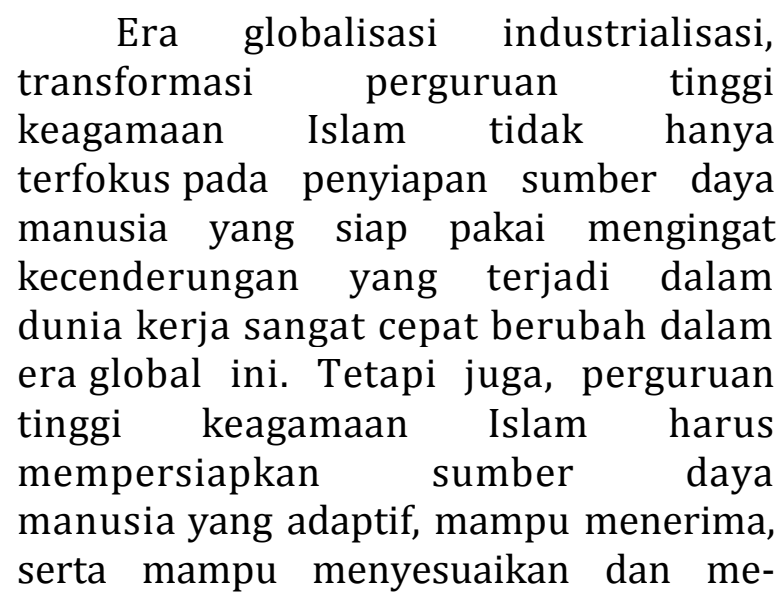

ngembangkan arus perubahan yang terjadi dalam lingkungannya.

Kualitas sumber daya manusia yang dihasilkan perguruan tinggi keagamaan Islam tidak hanya dapat diukur relevansinya secara internal yaitu berdasarkan kecocokan kualitasnya dengan sistem pendidikan tetapi juga harus memungkinkan kualitas tersebut dapat diukur relevansinya secara eksternal yaitu sesuai atau tidak dengan kebutuhan masyarakat, dalam dunia ekonomi, industri, budaya, maupun yang lainnya. Format ideal perubahan PTKIN relevansinya adalah dapat diukur dengan kesanggupannya untuk bersaing secara global. Kemajuan tidak hanya diukur oleh kemampuannya berswasembada, tetapi juga diukur oleh kemampuannya untuk mempertahankan diri, mengimbangi, bahkan mengalahkan kekuatan yang datang dari luar, khususnya yang berhubungan dengan kegiatan-kegiatan yang mengembangkan kemakmuran masyarakat dan kemampuan berkompetisi sebagai bangsa di hadapan bangsa-bangsa lain. [] 


\section{DAFTAR RUJUKAN}

Abdullah, Amin. Integrasi Epistimologi Keilmuan dan Agama, Jakarta: INCIS, 2004.

Abdullah, Amin. Mencari Islam: Studi Islam dengan Berbagai Pendekatan. Yogyakarta: Tiarawacana, 2000.

Al-Faruqi, Ismail Raji. Islamization of Knowledge, Series (3), (United States of America: The International Institute of Islamic Thought, 2009.

Ali, Fachry. Kontinuitas dan Perubahan: Catatan Sejarah Social Budaya Alumni IAIN dalam Problem dan Prospek IAIN. Jakarta: Ditbinperta, 2007.

Daulay, Haidar Putra. Dinamika Pendidikan Islam di Asia Tenggara. Jakarta: Rineka Cipta, 2009.

Dewi, Diana Candra. "Tantangan Global UIN", Perta: Jurnal Inovasi Pendidikan Tinggi Agama Islam, 7.2 (2004).

Djohar, M.S. "Pendidikan Alternatif: Mencari Terobosan Baru dalam KemandeganPendidikan di Indonesia", yang disampaikan pada seminar tentang Pemikiran dan Metodologi Pendidikan, oleh LP3 dan FAI UMY. pada tanggal 25 Pebruari 2007.

Djumransyah. "Mencari Paradigma Sistem Pendidikan Tinggi Islam Masa Depan", Malang: Majalah Tarbiyah, Nomor: 42, Tahun 2006.

Fadjar, A. Malik. "Pengembangan Pendidikan Islam yang Menjanjikan Masa Depan", dalam Mudjia Rahardjo (ed), Quo Vadis Pendidikan Islam: Pembacaan Realitas Pendidikan Islam, Sosial dan Keagamaan, Malang: UIN Malang Press, 2006.

Fadjar, A. Malik. Holistika Pemikiran Pendidikan, Jakarta: Raja Grafindo, 2005.

Idris, Muhammad. Pemberdayaan Kualitas Umat Menuju Masyarakat Madani (Sebuah opsi memasuki masyarakat yang membebaskan), Makassar: PPs UIN Makassar, 2008.

Idris, Muhammad. Visi dan Praksis A.Malik Fadjar Dalam Pengembangan Pendidikan Islam. Jakarta: Disertsi PPS UIN Jakarta, 2008.

Kusmana dan Yudi Munadi (ed.). Proses Perubahan IAIN Menjadi UIN Syarif Hidayatullah Jakarta. Ciputat: UIN Press, 2002.

Mulia, Siti Musdah. "PTAI Hadapi Tantangan Sangat Berat". Perta: Jurnal Inovasi Pendidikan Tinggi Agama Islam, 8.2 (2004).

Mulkhan, Abdul Munir. "Refleksi Humanisasi Tauhid Dalam Reformasi Ontologis Pendidikan Islam." Jurnal Ilmu Pendidikan Islam, 2.1 (2001).

Nata, Abudin (ed.). Paradigma Pendidikan Islam. Jakarta: Grasindo, 2010.

Nata, Abudin (ed.). Sejarah Pertumbuhan dan Perkembangan Lembagalembaga Pendidikan Islam di Indonesia. Jakarta: PT Grasindo, 2005.

Rahman, Fazlur. Islamic Methodology in History. Islamabad: Islamic Research Institute Press, 1994.

Shodiq, Abdullah. " Rekonsiliasi Epistemologi: Ikhtiar Mengatasi Dikhotomi Ilmu dalam Pendidikan Islam", dalam Ismail SM. dkk (ed). Paradigma Pendidikan Islam. Yogyakarta: Pustaka Pelajar, 2007.

Suprayoga, Imam. Tarbiyah Uli al-Albab: Dzikir, Fikr, dan Amal Shaleh. Malang: UIN Malang Press, 2004.

Suwito, dan Suprapto. "IAIN Menjadi Universitas?", Mimbar Agama dan Budaya, 18.2 (2001).

Zamaroni. Paradigma Pendidikan Masa Depan. Yogyakarta: Biograf Publishing, 2000. 